\title{
Studies on Endophytes Isolated from Rose and Soyabean
}

\author{
A.V. Jawanjal and D.L. Barate* \\ Department of Microbiology, Shri Shivaji College of Arts, Commerce and Science, \\ Akola 444001 (M.S.), India \\ *Corresponding author
}

\section{A B S T R A C T}

Keywords

Endophytes, Rose, Soyabean, IAA.

Article Info

Accepted:

26 May 2017

Available Online:

10 June 2017
Microorganisms that live in plant tissues without causing disease symptoms are termed as endophytes. In present study, mature healthy plant materials from Rose and Soyabean were collected; totally 35 endophytic bacteria and 15 fungi were isolated. On the basis of standard conventional methods the bacteria found to belongs to the genus Staphylococcus, Pseudomonas, Bacillus and Serratia. 10 bacteria and 7 fungi showed antimicrobial activity against Staphylococcus aureus, Escherichia coli and Pseudomonas aeroginosa. Eleven endophytic bacteria and 4 endophytic fungi had shown positive IAA test.

\section{Introduction}

Microorganisms that live in plant tissues without causing disease symptoms are termed as endophytes. Each plant is a host of endophytes, though only a small part of them is so far described (Miliate and Buzaite, 2011). Endophytic bacteria seem to be ubiquitous in most plant species and have been isolated from roots, leaves, and stems, and a few from flowers, fruits, and seeds. Endophytic bacteria may accompaniment certain metabolic properties, such as promoting plant growth, controlling soil borne pathogses, or helping host plant to defeat stress responses to environmental abuse. Furthermore, the interactions between plants and bacteria help plants to settle in ecosystem restoration processes. These interactions may increase the ability of plants to utilize nutrients from the soil by increasing root development, nitrate uptake, or solubilizing phosphorus, and to control soilborne pathogens (EL-Deep et al.,2012).

For exploring biodiversity of endophytes in the study two plants were selected namely Rose and Soyabean which are mayor crops from economic point of view. The Rose plant belongs to the family Rosaceae. It was previously found that Bacillus species. Methylococcus species, Acinetobacter species, Micrococcus species, inhabit in rose plant as endophytes (Bahig El-Deeb et al., 2015).

There is less information available about bacterial and fungal communities which are associated with different parts of rose plant. Soyabean is a major world crop, there is very 
limited knowledge of its fungal endophyte community. The mis-usage of antibiotics since the "Golden Age of Antibiotics" in 1950s had caused the threats of antibiotic resistant "superbugs". Hence, there is an evergrowing need for new and useful compounds to provide assistance and relief in all aspects of the human condition. Both human pathogens and fungal phytopathogens are prone to develop "drug" resistances. The effectiveness of the older types of antibiotics can decrease substantially. In addition, because of safety and environmental problems, many synthetic agricultural agents have been and still are targeted for removal from the market. The removal of such agents creates a need to find alternative ways to control farm pests and pathogens (Tong et al., 2011).

\section{Materials and Methods}

\section{Collection and surface sterilization of plant material}

Samples were collected. Sample were washed in running tap water for 10 minutes to remove soil particles and adhered debris and finally washed with distilled water and surface sterilization was done. Sample were immersed in $70 \%$ ethanol for 1-3 minutes and $4 \%$ aqueous solution of sodium hydrochloride 3 minutes, again treated for one minute with $70 \%$ ethanol and $0.1 \%$ mercuric chloride 2 minute. Finely rinse with sterile distilled water 3 times.

\section{Isolation of endophytes}

For the isolation of endophytes the sample tissues were crushed with glass rod so that inner tissue excised. Those tissues were inoculated on to the nutrient agar medium for 24 to $48 \mathrm{hrs}$. At $37^{\circ} \mathrm{C}$, to isolate endophytic bacteria, and for isolation of endophytic fungi, samples were inoculated on to the potato dextrose agar, containing chloramphenicol as to avoid bacterial growth and incubated for 6 to 7 days, at room temperature.

\section{Determination of antimicrobial activity}

The antimicrobial activity was done by using well diffusion method. endophytic bacterial isolates were inoculated in nutrient broth and incubated for $24 \mathrm{hrs}$. At $37^{\circ} \mathrm{C}$ while endophytic fungi isolates were grown in Czapek Dox Broth for 3-4 days at orbital shaker incubator. After incubation, centrifugation at $6000 \mathrm{rpm}$ for $25 \mathrm{~min}$ was done $\&$ cell free supernatant were separated to check the antimicrobial potential.

The 24hrs old incubated broth culture of each human pathogenic bacteria were spread on Mueller Hinton agar with the help of sterile cotton swab and the well of $0.5 \mathrm{~mm}$ were made with the help of sterilized cork borer. After that $100 \mu \mathrm{l}$ of cell free supernatant was introduced into the well with the help of micropipette. The plates were incubated for 24 hours at $37^{\circ} \mathrm{C}$. The antimicrobial activity was recorded as +ve according to the zone of inhibition around the well.

\section{Estimation of IAA production by endophytes}

For the determination of IAA production by isolates, cultures were inoculated in $5 \mathrm{ml}$ of Luria Bertani Broth amended with 2tryptophan at the rate of $100 \mathrm{ug}$ per $\mathrm{ml}$. The test tubes were incubated at $30^{\circ} \mathrm{C}$ for $24 \mathrm{hrs}$ for bacteria, and 3-4 days incubation for fungi on orbital rotary shaker incubator.

After incubation the broth was centrifuged at $1000 \mathrm{rpm}$ for $15 \mathrm{~min} .2 \mathrm{ml}$ of supernatant from respective isolates was collected and 2-3 drops of O-phosphoric acid were added. The aliquots were shaken and added $4 \mathrm{ml}$ of 
reagent $\left(1 \mathrm{ml}\right.$ of $0.5 \mathrm{M} \mathrm{FeCl}_{3}$ in $49 \mathrm{ml}$ of $35 \%$ Sulphuric acid. $\left(\mathrm{H}_{2} \mathrm{SO}_{4}\right)$. Then allow it to stands for $25 \mathrm{~min}$ at room temperature \& absorbance was read at $530 \mathrm{~nm}$. The emergence of pink-red colour indicated the production of IAA.

\section{Results and Discussion}

In the present study totally 35 endophytic bacteria were isolated from various plant material viz. Flower, stem, leaf of Rose and Soyabean plant. The occurrence of endophytic bacteria is shown in figure 1 . Total 23 endophytic bacteria were isolated from Rose plant and 12 from Soyabean plant (Table 1).

In the study, endophytic fungi were also isolated. A total of 15 fungi were isolated. The occurrence of endophytic fungi is shown in figure 2. Out of 15 fungal isolates 8 were isolated from soyabean plant and 7 were isolated from Rose plant (Table 2).

The isolated endophytes were then identified by Bergy's Manual of Determinative Bacteriology. The cultural, morphological and biochemical characteristic of endophytic bacteria were studied. On the basis of these standard conventional methods the bacteria were found to belong to the genus Staphylococcus, Pseudomonas, Bacillus and Serratia as shown in table 3.

The endophytic fungi are given in table 4 . The founded fungi were belongs to Aspergillus spp., Fusarium spp and Penicillium spp. The antimicrobial activity of the endophytic bacteria and fungi is given in figure 4, 5 and 6 . For this activity 3 clinical pathogens were used as a test organism, Staphylococcus aureus, Escherichia coli and Pseudomonas aeruginosa, to evaluate the antimicrobial activity of endophytic isolates.

IAA production by endophytic bacteria is given in figure 7 . Eleven bacteria out of 35 showed IAA test positive while other showed negative. The absorbance at IAA positive bacteria at $530 \mathrm{~nm}$ was recorded. It was found that IAA production was maximum for RFB9 and RFB3.

IAA production by endophytic fungi was also checked (Figure 8). Four endophytic fungi out of 15 had shown positive IAA test while other showed negative.

The absorbance of endophytic fungi at 530 nm was recorded. The highest production of IAA was recorded for SLF11 and minimum for RSF7.

Total 23 bacteria were obtained from flower, stem and leaf of rose plant. From soyabean 12 bacteria were obtained from stem and leaf. The similar investigation was carried out by Arora et al., 2014 as they investigate 20 bacteria from salt tolerant plant. Seven endophytic fungi were obtained from flower, stem and leaf of rose plant.

Table.1 Occurrence of endophytic bacteria from rose and soyabean plant

\begin{tabular}{|l|l|l|l|l|}
\hline Plants & Flower & Stem & Leaf & Total \% \\
\hline Rose & $9(25.71 \%)$ & $8(22.85 \%)$ & $6(65.7 \%)$ & $23(65.7 \%)$ \\
\hline Soyabean & - & $7(20 \%)$ & $5(14.28 \%)$ & $12(53.33 \%)$ \\
\hline
\end{tabular}

Table.2 Occurrence of endophytic fungi from rose and soyabean plant

\begin{tabular}{|l|l|l|l|l|}
\hline Plants & Flower & Stem & Leaf & Total \% \\
\hline Rose & $2(13.33 \%)$ & $2(13.33 \%)$ & $3(20 \%)$ & $7(46.66 \%)$ \\
\hline Soyabean & - & $3(20 \%)$ & $5(33.33 \%)$ & $8(53.33 \%)$ \\
\hline
\end{tabular}


Table.3 Prevalence of endophytic bacteria from rose and soyabean plant

\begin{tabular}{|l|l|c|c|}
\hline S.No. & Name of bacteria & Number & Percentage (\%) \\
\hline 1 & Pseudomonas aeruginosa & 10 & 28.57 \\
\hline 2 & Bacillus cereus & 8 & 22.85 \\
\hline 3 & Staphylococcus aureus & 7 & 20 \\
\hline 4 & Serratia marcescens & 5 & 14.28 \\
\hline 5 & Bacillus subtilis & 4 & 11.42 \\
\hline
\end{tabular}

Table.4 Prevalence of endophytic bacteria from rose and soyabean plant

\begin{tabular}{|l|l|c|c|}
\hline S.No. & Name of Fungi & Number & Percentage (\%) \\
\hline 1 & Aspergillus spp. & 6 & 40 \\
\hline 2 & Fusarium spp. & 5 & 33.33 \\
\hline 3 & Penicillium spp. & 4 & 26.66 \\
\hline
\end{tabular}

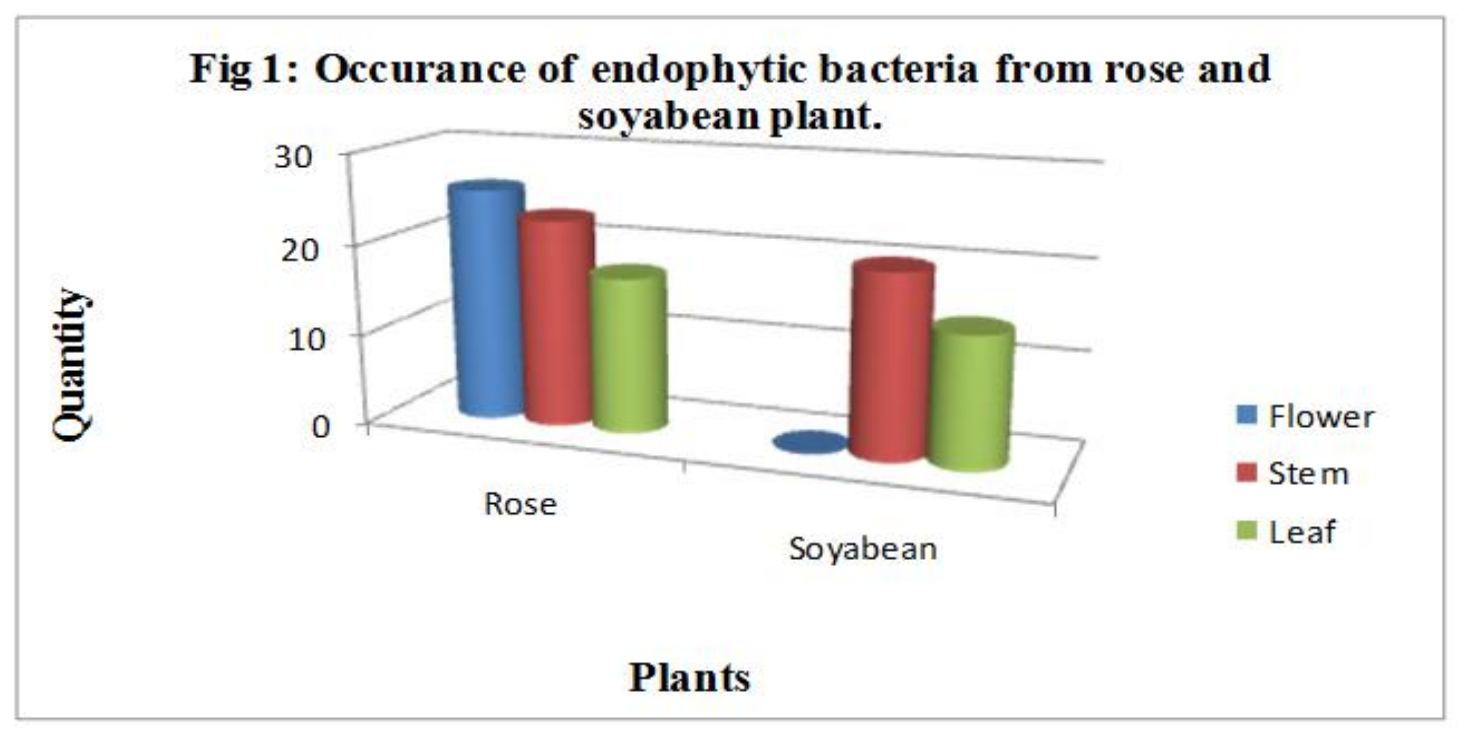

Fig 2: Occurance of endophytic fungi from rose and soyabean plant.

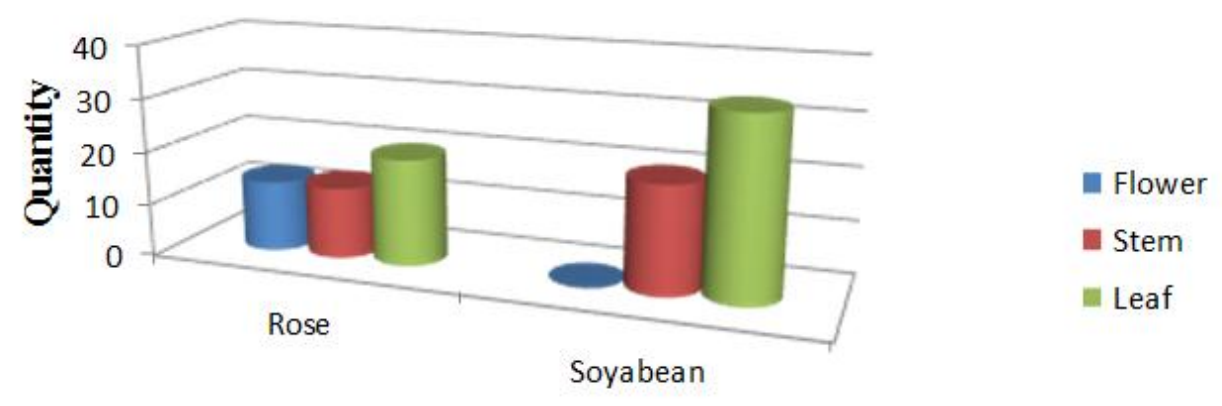

Plants 
Fig 3: Antimicrobial activity of endophytic bacteria against

S. aureus.

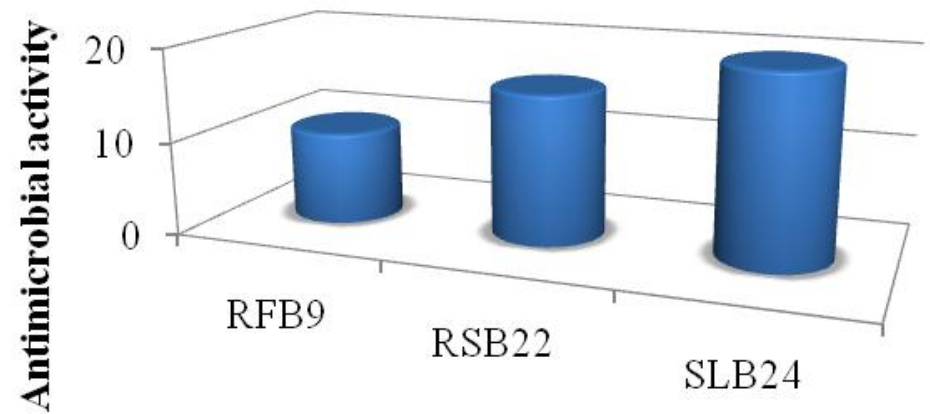

Bacterial endophytes

Fig 4: Antimicrobial activity of endophytic bacteria against Pseudomonas aeruginosa.

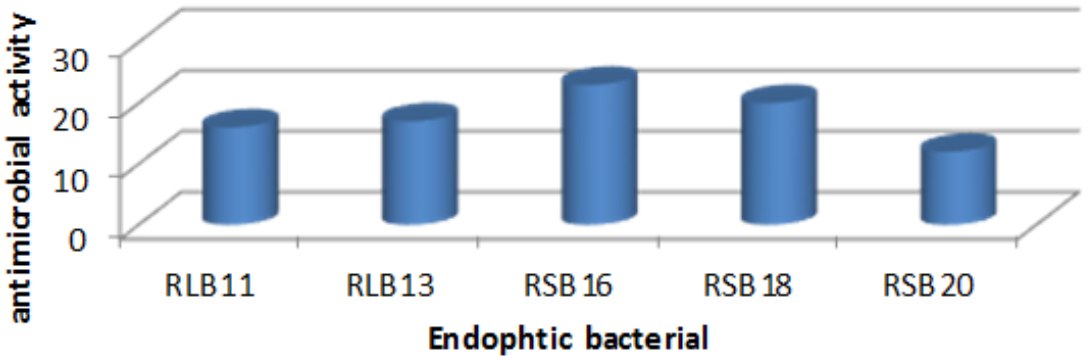

Fig 5 Antimicrobial activity of endophytic bacteria against E. coli.

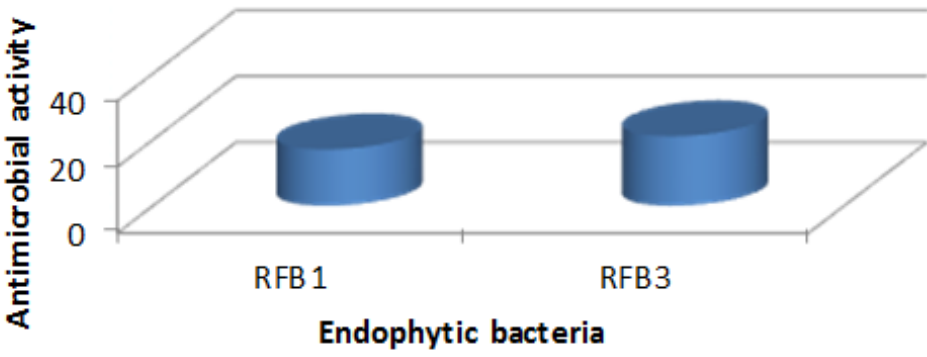


Fig 6:. Antibacterial activity of fungal endophytes against clinical pathogens

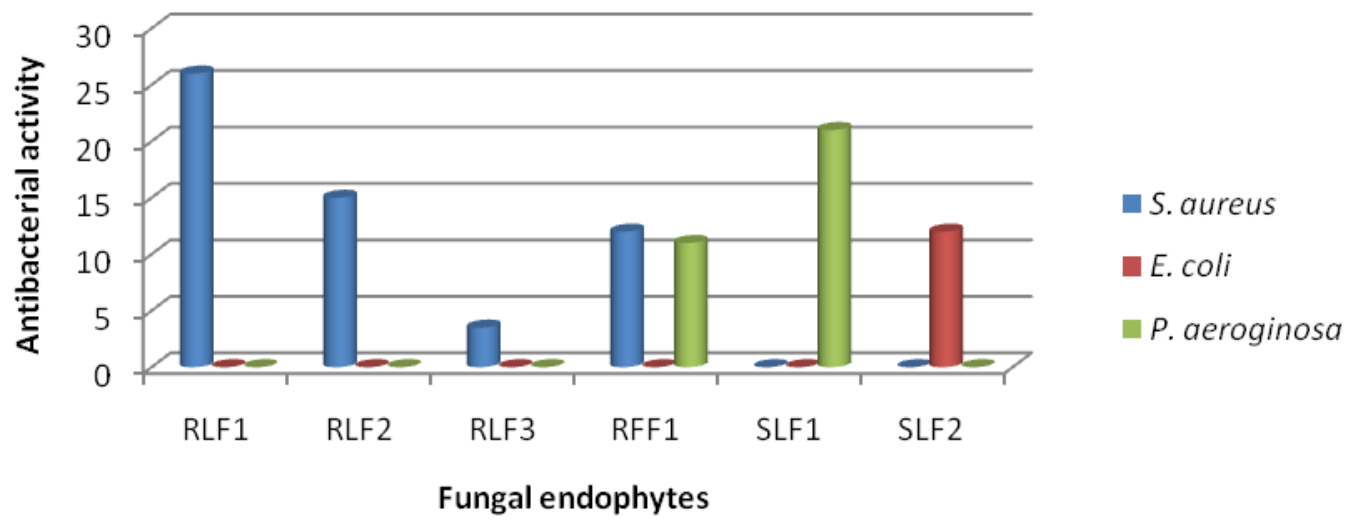

Fig 7: Determination of IAA production by endophytic fungi.

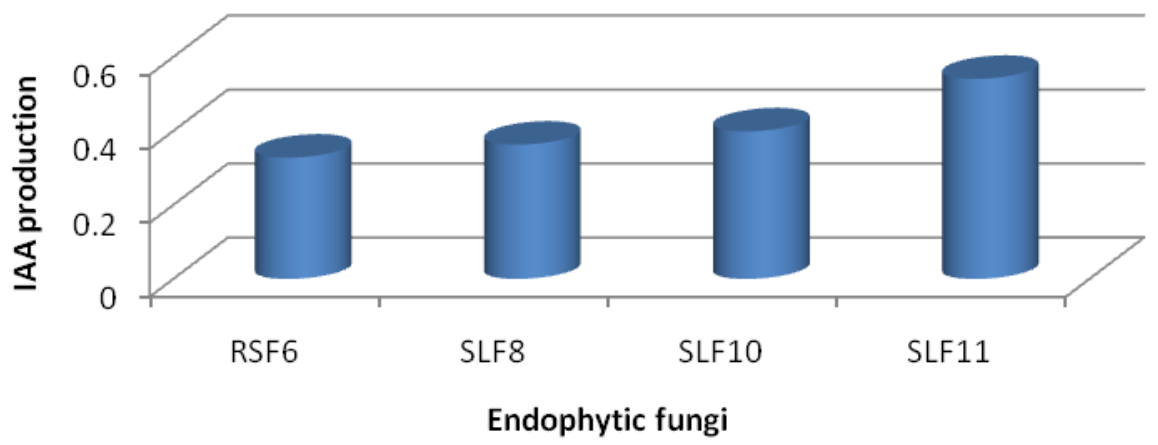

Fig 8: Determination of IAA production by endophytic bacteriat

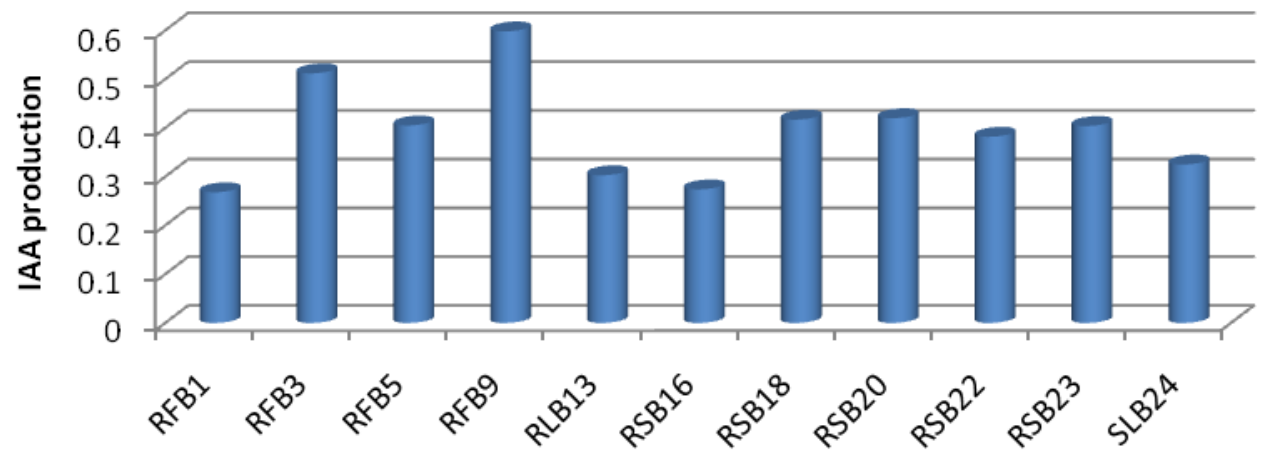

Endophytic fungi 


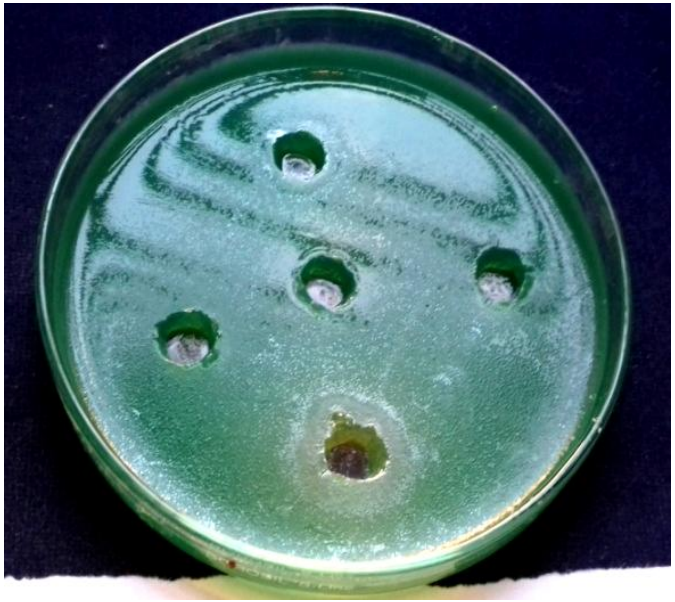

Picture.1 Antimicrobial activity of endophytes

From soyabean plant 8 fungi were obtained from stem and leaf. The similar investigation was carried out by Shebany et al., (2014) as isolation and identification of endophytic fungi from leaves and roots of Altheae rosae.

Morphological and cultural characteristics of the bacterial isolates were studied. Total 35 isolates of bacteria and were obtained from rose and soyabean plant. Morphologically and culturally, all the bacteria differ in shape, size, colour, margin, elevation, opacity, motility and gram characteristics. The bacteria were also differ in biochemical characteristics. The aggremental results were obtained by Arora $e t$ al., (2014).

The antimicrobial activity of the endophytic bacteria were investigated against the clinical pathogens via. Staphylococcus aureus, Escherichia coli and Pseudomonas aeruginosa. Zone of inhibition clarified the antimicrobial activity. The results shown were in accordance to Vijayalakshmi et al., (2016) as enzyme production and antimicrobial activity of endophytic bacteria isolated from medicinal plant. The antimicrobial activity of endophytic fungi were in accordance with Bisht et al., 2016 as antagonistic activity of endophytic fungi isolated from needle of Cupressus trulosa (Picture 1)

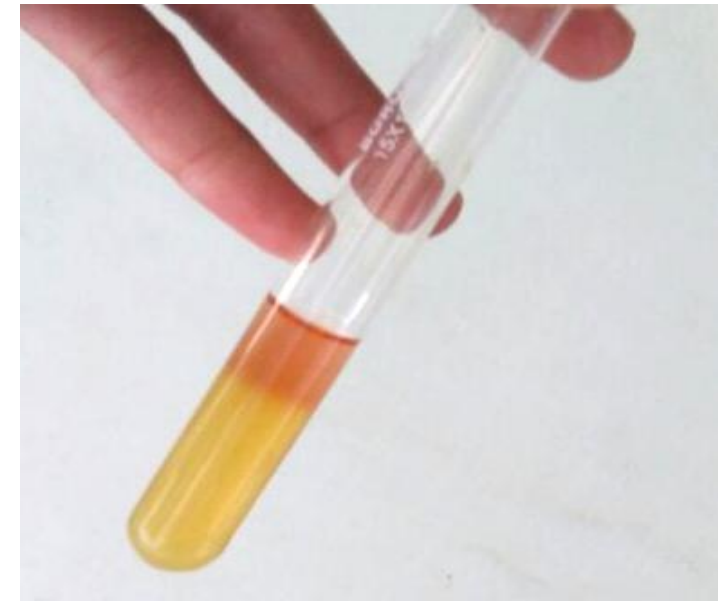

Picture.2 IAA production by endophytes

Eleven bacteria out of 35 and 4 endophytic fungi out of 15 had shown positive IAA test while other showed negative. The absorbance at IAA positive bacteria as well as fungi at $530 \mathrm{~nm}$ were measured. Many of the endophytic bacteria and endophytic fungi had shown better IAA production which is a good indicator of future study belonging to IAA production in future. The similar investigation were carried out by Lines et al., (2014) as plant growth promoting potential of endophytic bacteria isolated from Cashew leaves and by $\mathrm{Yu}$ et al., (2016) as isolation and characterization of indole acetic acid producing root endophytic bacteria and their potential for promoting crop growth (Picture 2).

The endophytes isolated from Rose and Soyabean plant were found to belongs the Genus Bacillus, Pseudomonas, Serratia and Staphylococcus, while fungi from Fusarium, Penicillium, Aspergillus. The 8 bacterial endophytes and 6 fungal endophytes showed varied antimicrobial potential against clinical pathogens. Twelve endophytic bacteria showed IAA production from 35 isolates while 4 out of 15 fungal isolates showed IAA production. RFB9 from bacterial endophytes and SLF4 from fungal endophytes showed high IAA production. Many of these isolates 
has shown antimicrobial activity and IAA production can be useful for exploitation of production of bioactive compounds and also in plant growth promotion in future after detailed investigation.

\section{References}

Arora Sanjay, Patel Purvi N., Vanza Meghna J., Rao G. G (2014). Isolation and characterization of endophytic bacteria colonizing halophyte and other salt tolerant plant species from coastal Gujrat. African journal of microbiology research; vol. 8(17):1779-1788.

Bisht Rinky, Sharma Deeksha, Agrawal Pawan Kumar (2016). Antagonistic and antibacterial activity of endophytic fungi isolated from needle of Cupressus Torulosa d. don. Asian journal of pharmaceutical and clinical research; vol.9 (3):282-288.

El-Deep Bahing, Bazaid Salih, Gherbawy Youssuf, Elhariry Hesham. Characterization of endophytic bacteria associated with rise plant (Rose damascena trigintipeta) during flowering stage and their plant growth promoting traits. Journal of plant interaction. 2012; Vol. 7(3):248-253.

Hung Phan Quang, Annapurna K. isolation and characterization of endophytic bacteria in soyabean (Glycine $s p$ ). Omonrice. 2004; vol.12:92-101.

Lins Milca Rachel Da Costa Ribeiro, Fontes Jessica Martins, Vasconcelos Nataliane Marques de, Santos Danilo Mamede da Silva, Ferreira Ozias Elias, Azevedo Joao Lucio de, Araujo Janete Magali de,
Lima Glaucia Manoella de Souza (2014). Pant growth promoting potential of endophytic bacteria isolated from cashew leaves. African journal of biotechnology; vol.13 (33):3360-3365.

Miliute Inga, Buzaite Odeta (2011). IAA production and other plant growth promoting traits of endophytic bacteria from apple tree. Lietuvos mokslu akademija, 57(2): 98 - 102.

Shebany Yassmin M., El-Magraby Osman M. O., Abdel-Wahab Mohamed A., Magraby Thanaa A (2014). Isolation and identification of endophytic fungi from leaves and roots of Altheae rosea. International journal of life sciences research; vol.2 (4):48-57.

Tong W. Y., Darah I., Latiffah Z. Antimicrobial activities of endophytic fungal isolates from medicinal herb Orhosiphon stamineus Benth. Journal of medicinal plants research. 2011; vol.5 (5):831-836.

Vijayalakshmi R., Kairunnisa K., Sivvaswamy S. Narender, Dharan Soumya S., Nataranjan S (2016). Enzyme production and antimicrobial activity of endophytic bacteria isolated from medicinal plants, Indian journal of science and technology; vol 9(14):1-8.

Yu J., Yu Z. H., Fan G, Q., Wang G. H., Liu X. B (2016). Isolation and characterization of indole acetic acid producing root endophytic bacteria and their potential for promoting crop growth. Journal of agriculture science technology; vol.18: 1381 - 1391.

\section{How to cite this article:}

Jawanjal, A.V. and Barate, D.L. 2017. Studies on Endophytes Isolated from Rose and Soyabean. Int.J.Curr.Microbiol.App.Sci. 6(6): 2074-2081.

doi: https://doi.org/10.20546/ijcmas.2017.606.246 